TITLE:

\title{
Origin of Climbing Fiber Neurons and Their Developmental Dependence on Ptfla(Abstract_要 旨)
}

$\operatorname{AUTHOR(S):~}$

Yamada, Mayumi

\section{CITATION:}

Yamada, Mayumi. Origin of Climbing Fiber Neurons and Their Developmental Dependence on Ptfla. 京都大学, 2010, 博士(医学)

ISSUE DATE:

2010-03-23

URL:

http://hdl.handle.net/2433/120572

RIGHT: 
